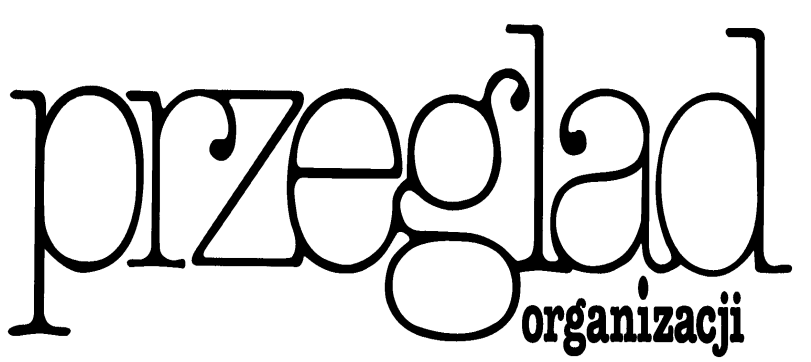

https
Marka i jej
znaczenie
w przedsię-
biorstwie

https://doi.org/10.33141/po.2005.04.02

\section{Barbara Józefowicz}

Przegląd Organizacji, Nr 4 (783), 2005, ss. 13-16 www.przegladorganizacji.pl

Towarzystwo Naukowe Organizacji i Kierownictwa (TNOiK)

\section{Definicje marki w literaturze}

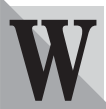

literaturze naukowej często spotyka się definicję opracowaną w latach 60. przez Amerykańskie Stowarzyszenie Marketingu. Według niej marka jest to „nazwa, termin, symbol, wzór lub ich kombinacja, stworzona celem identyfikacji dóbr lub usług sprzedawcy lub ich grupy i wyróżnienia ich spośród konkurencji”"1). Obecnie jednak okazuje się ona dalece niewystarczająca, gdyż utożsamia markę ze znakiem towarowym, pojęciem używanym w literaturze prawniczej i aktach prawnych, określajacym jedynie zakres ochrony prawnej2). A jak obecnie twierdzi $\mathrm{Ph}$. Kotler: ,jeśli nie jest niczym więcej, jak tylko nazwą, to jako marka jest klęską" ${ }^{3)}$. Niektórzy autorzy próbują więc udoskonalać tę definicję dodając, że jest to „dowolne słowo, pomysł (rysunek, dźwięk, kształt lub kolor)" "). Jednak, jak to trafnie ujął Z. Waśkowski „marka jest czymś więcej, zawiera bowiem w sobie przesłanie, pozytywne skojarzenia, niesie wiele wartości, za które nabywcy chcą płacić wyższą cenę"5). Wykraczajac poza waskie rozumienie, profesor J.P. Jones definiuje markę jako „produkt, który dostarcza korzyści funkcjonalnych oraz wartości dodanej, które pewni konsumenci cenią w wystarczajaccym stopniu, aby dokonać zakupu"6). Tę definicję przytacza też J. Altkorn jako łączącą w sobie trzy najpopularniejsze znaczenia kryjące się pod tym pojęciem ${ }^{7)}$. Oprócz wspomnianego już znaku towarowego, mówiąc o marce rozumie się także konkretny produkt, linię produktu, rodzinę produktów lub cały asortyment oferowany przez określoną firmę. Może też chodzić o rynkowy wizerunek produktów i/lub organizacji, która je oferuje i wtedy określenie „marka” ma sens wyraźnie wartościujący, w potocznej polszczyźnie najczęściej wyrażajacy opinię.

J. Kall proponuje, aby marką nazywać „kombinację produktu fizycznego, nazwy marki, opakowania, reklamy oraz towarzyszących im działań z zakresu dystrybucji i ceny, kombinację, która odróżniając ofertę danego marketera od ofert konkurencyjnych, dostarcza konsumentowi wyróżniających korzyści funkcjonalnych i/lub symbolicznych, dzięki czemu tworzy lojalne grono nabywców i umożliwia tym samym osiągnięcie wiodącej pozycji na rynku"s).

Z kolei piękne i niemal poetyckie wyjaśnienie prezentuje M.A. Boruc pisząc, że: „marka to całościowy, symboliczny, unikatowy wizerunek firmy, wyróżnia- 
jący ją na rynku w ten sposób, że kojarzy się konsumentowi z czymś doskonałym, pożądanym, godnym szacunku i podziwu, jedynym, niepowtarzalnym"9). Nazwa staje się więc marką, gdy jest utożsamiana z „pewną osobowością"10). Aby jednak było to możliwe, niezbędne są ogromne nakłady i wiele lat pracy odpowiednich ludzi.

Według L. De Chernatony’ego i McDonalda „marka odnosząca sukces to możliwe do zidentyfikowania produkt, usługa, osoba lub miejsce, uzupełnione o trwałe wartości uznawane przez nabywcę lub użytkownika za odpowiednie, takie, które w najwyższym stopniu zaspokajają jego potrzeby"11). Uznają oni, że marka jest czymś więcej niż wiązką wartości funkcjonalnych i emocjonalnych. Jest elementem integrującym wszystkich interesariuszy firmy z przedsiębiorstwem.

Jak dało się zauważyć, istnieje ogromna różnorodność definicji marki. Wszystkie występujące w literaturze sposoby rozumienia tego, czym jest marka, zgrupować można w trzech kategoriach interpretacji ${ }^{2}{ }^{2}$ :

- $\mathrm{z}$ perspektywy wkładu - z punktu widzenia menedżerów zarządzających zasobami w celu wywarcia wpływu na konsumentów:

$\checkmark$ logo - wizualne oznaczenia marki są podstawą do jej rozróżniania,

$\checkmark$ instrument prawny - gwarancja ochrony praw własności,

$\checkmark$ firma - dominacja marki firmy w całej strategii marki,

$\checkmark$ zapis stenograficzny - skrót skojarzeniowo-informacyjny,

$\checkmark$ czynnik ograniczający ryzyko - rzeczywista gwarancja jakości,

$\checkmark$ pozycjonowanie - zapewnienie natychmiastowych skojarzeń klienta przy zetknięciu z marka, z konkretnymi korzyściami funkcjonalnymi,

$\checkmark$ osobowość - niepowtarzalny charakter marki zapewnia wyposażenie jej w wartości emocjonalne, które niektórzy użytkownicy cenią sobie czasem wyżej niż użyteczność funkcjonalną,

$\checkmark$ wiązka wartości - wyróżnianie marki poprzez nadanie jej własnego systemu wartości, decydująco wpływa na zachowania nabywców,

$\checkmark$ wizja - wyraźnie wskazuje rolę, jaką marka spełnia w swoim otoczeniu, zachęcając do podejmowania konkretnych działań,

$\checkmark$ dodawanie wartości - dodatkowe korzyści cenne dla klientów,

$\checkmark$ tożsamość - etos, wartości i cele, które reprezentują wyróżniające daną markę poczucie indywidualności;

- z perspektywy wyników - z punktu widzenia konsumentów, z uwzględnieniem sposobu, w jakim marki pozwalają nabywcom osiągnąć więcej:

$\checkmark$ wizerunek - zestaw skojarzeń spostrzeganych przez jednostki w pewnym czasie, w rezultacie bezpośredniego lub pośredniego zetknięcia $\mathrm{z}$ marką,

$\checkmark$ związek - wzajemne relacje klienta ze spersonifikowaną marką;

- z perspektywy czasu - jako podmiot podlegający ewolucji na skutek ciągłej konsumeryzacji, przeszedł następujące chronologicznie etapy ${ }^{13)}$ :

$\checkmark$ towary niemarkowe,

$\checkmark$ referencje - nazwa stosowana jako identyfikator, $\checkmark$ osobowość - oferująca poza korzyściami produktu korzyść emocjonalną,

$\checkmark$ ikona - symbol,

$\checkmark$ firma - przewaga korzyści korporacyjnych i zintegrowana komunikacja,

$\checkmark$ polityka - marka jest związana z kwestiami o charakterze społecznym i politycznym, do których konsumenci przywiązują znaczenie.

Charakterystyczny w tej ewolucji jest sposób patrzenia na markę od strony przedsiębiorstwa, przekształcający się do spojrzenia z punktu widzenia konsumenta.

\section{Interpretacje marki w praktyce}

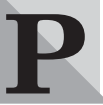

rzedstawione powyżej koncepcje marki nie wykluczaja się, lecz wzajemnie przenikaja i uzupełniają. Z przeprowadzonych w 1996 roku badań, z udziałem dwudziestu czołowych specjalistów z firm konsultingowych, agencji reklamowych, agencji badań rynku oraz firm o podobnym profilu znajdujacych się w Londynie wynika, że wszystkie interpretacje zawarte w literaturze znajdują swoje odzwierciedlenie w opinii ekspertów ${ }^{14}$. Najczęstsze pojmowanie marki przez praktyków gospodarczych obejmowało kilka definicji (przeciętnie 2-4), natomiast rzadko ograniczało się tylko do jednej. Dominującymi definicjami były: marka jako system wartości (11 wypowiedzi), jako osobowość (10), wizerunek (9) i logo (8).

Podobne badanie zostało przeprowadzone w Polsce w 2001/2002 roku przez pracowników naukowych Katedry Marketingu Wydziału Nauk Ekonomicznych i Zarządzania Uniwersytetu Mikołaja Kopernika w Toruniu. $\mathrm{O}$ zdefiniowanie $\mathrm{w}$ jednym zdaniu terminu „marka” poproszono właścicieli, dyrektorów, prezesów polskich firm różnej wielkości, branży i formy prawnej. Odpowiedzi respondentów przybierały najczęściej formę wymienionych po przecinku kilku znaczeń marki. Zdecydowanie najczęściej marka rozumiana była jako stała/ wysoka jakość (123 wskazania $31,5 \%$ ), a następnie jako ${ }^{15)}$ :

- logo, znak graficzny, znak firmowy, z którym kojarzą się produkty firmy (30 wskazań - 7,8\%);

- renoma firmy, wizerunek, prestiż, pozycja na ryn$\mathrm{ku}(27-6,9 \%)$;

- słowo, z którym kojarzą się produkty firmy (23 $5,9 \%)$

- solidność,doświadczenie,rzetelność,niezawodność, profesjonalizm, wiarygodność (20-5,1\%);

- towar cieszący się uznaniem na rynku, zaufaniem klientów $(16-4,1 \%)$;

- cecha umożliwiająca identyfikację towaru i producenta lub sprzedawcy $(10-2,6 \%)$;

- nazwa firmy (9-2,3\%);

- cecha wyróżniająca produkt na rynku (8-2\%);

- towar odróżniający się od innych na rynku (7 $1,8 \%$;

- zbiór korzyści dla nabywcy, wartość dla nabywcy $(7-1,8 \%)$;

- gwarancja uzyskania spodziewanego efektu związanego z zakupem produktu, małe ryzyko, bezpieczeństwo, pewność $(6-1,5 \%)$;

- wizytówka firmy, świadectwo firmy (6 - 1,5\%);

- gwarancja zadowolenia dla klienta $(2-0,5 \%)$.

W definicjach reprezentantów polskich przedsiębiorstw również widać ogromna różnorodność. Marka symbolizuje określone cechy, funkcje i właściwości 
produktu, jest szerokim i skomplikowanym pojęciem. Jej sformułowanie w klasycznej postaci (przez Amerykańskie Stowarzyszenie Marketingu) ustępuje miejsca szerszym definicjom związanym z korzyściami oferowanymi klientom. Jakkolwiek różnorodne są definicje marki, nie ulega wątpliwości, że jej znaczenie ciągle rośnie, a dawne funkcje ulegają poszerzeniu.

\section{Tradycyjne funkcje marki}

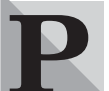

odstawową i najstarszą funkcją marki jest odróżnianie produktu firmy od dóbr i usług oferowanych przez inne organizacje. Dla producenta marka jest podobnym składnikiem produktu jak opakowanie czy usługi towarzyszące, jednak jej specyfika polega na tym, że w odróżnieniu od innych elementów odpowiada za psychologiczne zróżnicowanie produktu. Nawet, gdy produkty wykazują podobne cechy funkcjonalne, marka indywidualizuje produkt ${ }^{16}$. To właśnie wizualna odmienność umożliwia konsumentom identyfikację produktu, jego cech, a także pochodzenia. Stanowi to automatyczną ochronę przed konkurencją. Wyróżnianie chroni przed konkurencyjną rywalizacją ze względu na lojalność klientów wobec marki i wynikającą z niej mniejszą wrażliwość na cenę ${ }^{17)}$.

Dzisiejsza ekspansywność konkurencji, rosnaca turbulencyjność otoczenia, a co za tym idzie nasilająca się niepewność powodują, że na rynku wygrywa wcale nie największy, lecz najszybszy, najsprytniejszy i potrafiący zrobić najlepszy użytek z najnowszych technologii. Konkurowanie cena w większości branż jest nieefektywne, gdyż konsumenci coraz częściej sięgają po produkty markowe, które darzą zaufaniem, świadomie płacąc za nie odpowiednio wyższą cenę. Przewaga osiągnięta dzięki szczególnym cechom oferowanych produktów lub usług jest bardzo krótkotrwała, ponieważ postęp technologiczny umożliwia konkurentom błyskawiczne skopiowanie wynalazku. Dopiero wykreowanie marki przyciągającej uwage umożliwi klientom dostrzeżenie danej oferty jako atrakcyjnej. W tym celu wszystkie działania przedsiębiorstwa, a nawet sprzedawane produkty muszą zostać podporządkowane marce ${ }^{18)}$. To ona umożliwia odróżnienie nowatorskiego produktu od imitacji i zapewnia wyłączność w danej kategorii, pełniąc funkcję ochrony prawnej przed naśladowcami. Marka w umyśle konsumenta buduje określony wizerunek i kształtuje oczekiwania co do ceny, jakości, niezawodności. Sygnalizuje klientom źródło pochodzenia produktu i chroni zarówno konsumenta, jak i producenta przed konkurentami, którzy mogliby próbować dostarczać produkty o identycznym wyglądzie ${ }^{19}$. Marka informuje również o tym, kto jest przedstawicielem danej oferty. Jest świadectwem własności, prawa i odpowiedzialności za nią. Istnieją dwa sposoby realizacji funkcji informacyjnej marki ${ }^{20)}$ :

- bezpośredni - gdy w nazwie i logo marki zawarty jest prosty, łatwo czytelny komunikat o produkcie, jego zastosowaniu, przeznaczeniu czy właściwościach;

- pośredni - gdy informacja o korzyściach i atrybutach marki jest następstwem skojarzeń lub sugestii.

Marka tłumaczy sens i istotę oferty, wyjaśnia znaczenie, które nadawane jest dzieki wieloletniej konsekwencji, przy okazji wytycza też granice wiarygodności oferty wskazując, w jakich obszarach jej wyróżniające cechy brzmią prawdziwie, a w jakich nadużywają zaufania nabywcy ${ }^{21)}$.
Ponieważ konsumenci nie sa w stanie zebrać wszystkich informacji o dostępności produktów, ich cenach i jakości, a chcą dokonywać racjonalnych wyborów, opierają się na markach, co obniża koszty pozyskania informacji. Również producenci markowych produktów, bardziej niż niemarkowych, starają się o osiągnięcie jak najwyższej jakości, aby nie stracić reputacji, którą sugerują się nabywcy ${ }^{22}$. Dzięki stosowaniu marek klienci mają ułatwione zadanie w interpretacji, przechowywaniu i przetwarzaniu dużych ilości informacji o produktach i usługach. Marki wpływają również na zaufanie klientów do podejmowanych decyzji zakupu. Postrzegana jakość i skojarzenia związane z marką mogą zwiększyć zadowolenie z jej użytkowania. Wszystko to prowadzi do uzyskania przez firmę wyższych marż za swoje produkty, a w konsekwencji do przewagi konkurencyjnej ${ }^{23)}$.

Posiadanie marki umożliwia producentowi posegmentowanie rynku ${ }^{24}$. Jest to bardzo ważna zasada marketingu, pozwalająca na jak najlepsze usatysfakcjonowanie klientów o różnych preferencjach. Optymalna kombinacja pożądanych cech (nie tylko praktycznych, materialnych, ale zwłaszcza tych symbolicznych, niewidocznych) jest inna dla różnych grup odbiorców. Dzięki markom producent ma możliwość wystosowania różnych ofert na różne segmenty ryn$\mathrm{ku}$, dostosowując je jednocześnie do specyficznych potrzeb wielu odbiorców.

Ściśle związana z funkcją wyróżniającą jest funkcja promocyjna marki. Aby marka dobrze spełniała swoja wielowymiarowa rolę, musi najpierw sama zostać wypromowana, uwzględniając szerokie spektrum informacji. Dobrze identyfikowalna marka jest bardzo ważną i przede wszystkim stałą podstawą całej promocji ${ }^{25)}$. Oznacza to, że marka może być stosowana przez przedsiębiorstwo jako element komunikowania się z nabywcami, poprzez wszelkie formy promocji. G. Urbanek wymienia następujące korzyści ze stosowania marek ${ }^{26)}$ :

- dzięki marce firma odpowiedzialna za produkt jest znana;

- firma jest w stanie reklamować swoje produkty i kojarzyć marki oraz ich charakterystyki w umysłach konsumentów;

- zwiększa się prestiż produktu wraz ze wzrostem znaczenia poszczególnych marek;

- produkty oznaczone marką mają łatwiejszy dostęp do kanałów dystrybucji i zwiększają siłę przetargową producenta w stosunku do dystrybutora;

- marka może być wykorzystywana do sprzedaży całego asortymentu produkcji;

- znana marka może pomóc przy wchodzeniu do nowej kategorii produktów.

Marka może być także miernikiem działań marketingowych przedsiębiorstwa. Jej siła odzwierciedla stopień efektywności oddziaływań na zachowania konsumentów i dystrybutorów wobec firmy.

\section{Nowoczesne funkcje marki}

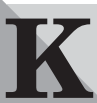

omunikacja przedsiębiorstwa z rynkiem za pośrednictwem marki umożliwia przekazywanie wielu informacji, co doprowadziło do wytworzenia się specyficznych więzi między markami a konsumentami, podobnych do tych, jakie zachodzą między ludźmi. W relacjach tych marka jest pewną osobowością, wyrażającą określone wartości 
i idee. Za jej pośrednictwem ludzie również porozumiewają się wzajemnie. Marka zwyczajnie ułatwia życie, nie tylko dlatego, że upraszcza decyzje zakupowe, ale przede wszystkim dlatego, że pomaga użytkownikom wyrazić siebie, swoje preferencje, uczucia i emocje. Świadomość używanej marki wzbogaca przeżycia, dostarcza dodatkowej satysfakcji, a nawet pewności siebie.

Mechanizm oddziaływania marki umożliwia powiązanie klienta z firma, daje szansę budowania lojalności klientów ${ }^{27)}$. Istnienie marek zapewnia konsumentom zmniejszenie odczucia ryzyka przy zakupie produktu, którego markę znaja i do której mają zaufanie. Marka żyje w pamięci nabywcy jako esencja doświadczeń związanych z zakupami i użytkowaniem produktów oraz skumulowana wiedza, przesłanie płynące $\mathrm{z}$ reklam, kształtuje postrzeganie marki w przyszłości. Gwarantujac trwałe utrzymywanie jakości na określonym poziomie, klienci odwdzięczają się właścicielowi marki gotowością do powtarzania zakupów i checcia rekomendowania marki innym nabywcom ${ }^{28)}$. Zmniejsza się wówczas oddziaływanie czynnika porównywania cen przy wyborze przez konsumenta. Wskutek tego ceny produktów oznaczonych silną marka mogą być ustalone na wyższym poziomie niż niemarkowych produktów tego samego rodzaju i o zbliżonym poziomie jakości, natomiast jednostkowe koszty działań marketingowych odnoszących się do silnych marek mogą być niższe. Znana i doceniana przez otoczenie marka jest także elementem minimalizujacym ryzyko nowych przedsięwzięć, stanowi gwarancję dla prowadzonego biznesu. Z powyższego wynikają następujące korzyści ${ }^{29)}$ :

- wyższa zyskowność sprzedaży,

- obniżenie cenowej elastyczności popytu w porównaniu z konkurentami,

- ułatwienie wydłużania linii produktów,

- ochrona producenta przed akcjami promocyjnymi konkurentów,

- wzmocnienie siły przetargowej w negocjowaniu warunków sprzedaży z pośrednikami,

- możliwość niemal nieograniczonego wydłużania cyklu życia

- szybsze łagodzenie ewentualnych niepowodzeń.

Obecnie powszechnie stało się już oczywiste, że podstawowa korzyścia z posiadania silnej marki jest jej wartość finansowa. Marka stała się aktywem do tego stopnia, że może być sprzedawana i kupowana za pieniądze; jest jednym $\mathrm{z}$ najistotniejszych elementów wartości przedsiębiorstwa i podobnie jak inne aktywa może być wyceniana. Z tego punktu widzenia budowanie marki można traktować również jako długoterminową inwestycję finansową.

O wartości marki decyduje jej zdolność do generowania przyszłych zysków, a więc skuteczność oddziaływania przedsiębiorstwa na nabywców za jej pośrednictwem. Z punktu widzenia gestora marki, spełnia więc ona funkcję strategiczna, jest narzędziem pozwalającym uzyskać trwałą przewagą konkurencyjną. Dlatego budowanie marki wymaga przeprowadzenia wielu analiz i uwzględnienia jej wielowymiarowej roli.

Barbara Józefowicz doktorantka na Wydziale Nauk Ekonomicznych i Zarzadzania Uniwersytetu Mikołaja Kopernika w Toruniu

\section{PRZYPISY}

1) Zob. m.in. Ph. KOTLER, G. ARMSTRONG, Principles of Marketing, Prentice Hall International, London 1989, s. 248; Ph. KOTLER, Marketing. Analiza, planowanie, wdrazanie $i$ kontrola, Gebethner i Ska, Warszawa 1994, s. 410; D. AAKER, Managing Brand Equity, Free Press, New York 1991, s. 7; G. URBANEK, Zarzadzanie marka, PWE, Warszawa 2002, s. 14, i inni.

2) „Znakiem towarowym może być każdy znak nadajacy się do odróżnienia towarów lub usług określonego przedsiebiorstwa od towarów lub usług tego samego rodzaju innych przedsiebiorstw. Znakiem towarowym może być w szczególności wyraz, rysunek, ornament, kompozycja kolorystyczna, forma plastyczna, melodia lub inny sygnał dźwiękowy bądź zestawienie tych elementów." - Ustawa z 31 stycznia 1985 r. o znakach towarowych (Dz.U. Nr 5, poz. 17 z późn. zm.); zob. też Ustawa z 30 czerwca 2000 r. - Prawo własności przemysłowej (Dz.U. Nr 49, poz. 508 z póź. zm.).

3) Zob. Ph. KOTLER, Kotler o marketingu. Jak kreować $i$ opanowywać rynki, Wydawnictwo Profesjonalnej Szkoły Biznesu, Kraków 1999, s. 93.

4) Zob. Z. PRZYBYŁOWSKI, S.W. HARTLEY, R.A. KERIN, W. RUDELIUS, Marketing, Dom Wydawniczy ABC 1998, s. 305; Podstawy marketingu, red. J. ALTKORN, Instytut Marketingu, Kraków 1996, s. 151.

5) Z. WASKOWSKI, Strategia marki, [w:] Strategie marketingowe, redaktor naukowy $\mathrm{H}$. MRUK, Wydawnictwo Akademii Ekonomicznej w Poznaniu, Poznań 2002, s. 121.

6) Zob. J.P. JONES, What's in the Name? Advertising and the Concept of Brands, Lexington 1986, s. 29.

7) Zob. J. ALTKORN, Strategia marki, PWE, Warszawa 1999, s. 11-12.

8) J. KALL, Silna marka. Istota $i$ kreowanie, PWE, Warszawa 2001, s. 11-12.

9) M.A. BORUC, Raport o marce, Polskie Stowarzyszenie Wytwórców Produktów Markowych PRO-MARKA, Warszawa 1999, s. 19.

10) J. MARCONI, Marketing marki. W jaki sposób tworzyć, zarzadzać $i$ rozszerzać wartość marki, Wydawnictwo K.E. LIBER, Warszawa 2002, s. 31.

11) L. de CHERNATONY, Marka. Wizja i tworzenie marki, Gdańskie Wydawnictwo Psychologiczne, Gdańsk 2003, s. 24.

12) L. de CHERNATONY, F. DALL'OLMO RILEY Defining a „Brand”: Beyond the Literature with Experts Interpretations, ,Journal of Marketing Management” 1998, nr 14; L. de CHERNATONY, Marka..., op.cit., s. 32-56.

13) M. GOODYEAR, Divided by a Common Language, „Journal of the Market Research Society” 1996, nr 38, s. $110-122$.

14) M. GOŁAWSKA, Definicje marki $w$ literaturze $i$ opinii ekspertów - cz. 2, „Marketing i Rynek” 1998, nr 12, s. 40.

15) Zob. I. ESCHER, "Strategie produktowe polskich przedsiębiorstw, [w:] Zarzadzanie marketingowe $w$ polskich przedsiebiorstwach. Stan, zastosowanie, tendencje $i$ kierunki zmian - tom I, Raport $\mathrm{z}$ badania, redaktor naukowy S. KACZMARCZYK, UMK, Toruń 2002, s. 72-73.

16) Zob. J. ALTKORN, Strategia..., op.cit., s. 13 .

17) Zob. M.E. PORTER, Strategia konkurencji. Metody analizy sektorów $i$ konkurentów, PWE, Warszawa 1994, s. 54 .

18) Zob. D.F. D'ALESSANDRO, Kreowanie marki, Wydawnictwo RM, Warszawa 2001, s. 10-12.

19) Zob. M. MARCINKOWSKA, Ksztattowanie wartości firmy, Wydawnictwo Naukowe PWN, Warszawa 2000, s. 136.

20) J. ALTKORN, Informacyjne funkcje znaków towarowych, "Handel Wewnętrzny” 1995, nr 5-6.

21) Zob. J. KALL, Silna marka..., op.cit., s. 16.

22) Zob. M. MARCINKOWSKA, Ksztattowanie..., op.cit., s. 138.

23) Zob. G. URBANEK, Zarzadzanie marka..., op.cit., s. 77.

24) Zob. Ph. KOTLER, Marketing. Analiza, planowanie..., op.cit., s. 413

25) Zob. J. ALTKORN, Strategia..., op.cit., s. 14.

26) G. URBANEK, Zarzadzanie marka..., op.cit., s. 24.

27) M. ZBORALSKI, Nazwy firm i produktów, PWE, Warszawa 2000, s. 31

28) Zob. M. WITEK-HAJDUK, Ksztattowanie marki, [w:] J. MAZUR (red.) Decyzje marketingowe $w$ przedsiębiorstwie, Difin, Warszawa 2002, s. 115.

29) Zob. J. KALL, Silna marka..., op.cit., s. 62-71. 